\title{
Hydrochemical Characteristics of Groundwater for Domestic and Irrigation Purposes in Dwarakeswar Watershed Area, India
}

\author{
Sisir Kanti Nag*, Anindita Lahiri \\ Department of Geological Sciences, Jadavpur University, Kolkata, India \\ Email: "nag_sk@yahoo.com
}

Received October 11, 2012; revised November 10, 2012; accepted November 18, 2012

\begin{abstract}
The Hydrochemical study was carried out in Dwarakeswar watershed area, Bankura and Purulia districts, West Bengal, India, with an objective of understanding the suitability of local groundwater quality for domestic and irrigation purposes. Groundwater samples have been collected from different villages within Dwarakeswar watershed area. The samples have been analysed to determine physical parameters like $\mathrm{pH}, \mathrm{EC}$, TDS and Hardness, the chemical parameters like $\mathrm{Na}, \mathrm{K}, \mathrm{Ca}, \mathrm{Fe}, \mathrm{HCO}_{3}, \mathrm{SO}_{4}$ and $\mathrm{Cl}$. From the analysed data, some parameters like Sodium Absorption Ratio (SAR), Soluble Sodium Percentage (SSP), Residual Sodium Carbonate (RSC), Total Hardness (TH), Magnesium Absorption Ration (MAR) and Kelly's Ratio (KR) have also been determined. The distribution pattern of TDS and chlorides, which are the general indicators of groundwater quality reveals that on an average the ground water is fresh and potable except the ground water in and around Teghari, Gara and Satyatan Primary school where the groundwater is not potable and may affect the health of local population because concentration of TDS exceeds the desirable limits of $500 \mathrm{mg} / \mathrm{L}$. The aerial distribution of Total Dissolved Solids (TDS) reveals that highest concentration is recorded at Gara and Teghri and the lowest concentrations is noted in Suburdih and Kalabani. SAR values were ranged between $0.09-0.54 \mathrm{meq} / \mathrm{L}$ in premonsoon and $0.01-0.24 \mathrm{meq} / \mathrm{L}$ in post-monsoon. It is evident from the whole sample set that the SAR value is excellent in all the samples. Hence, our findings strongly suggest that all the abstracted groundwater samples from the study area were suitable for irrigation. Results of analyses for physical and chemical parameters of groundwater in this area was found to be within the desirable Bureau of Indian Standards and World Health Organisation limits for drinking water.
\end{abstract}

Keywords: Groundwater Quality; Sodium Absorption Ratio (SAR); Irrigation Suitability; Drinking Water Suitability; Dwarakeswar Watershed

\section{Introduction}

Water is the most important resource for human existence. Ensuring access to cheap and clean drinking water is emerging as one of the most difficult challenges of this century. In rural side, there is an acute crisis of potable water with some of the water pockets containing excess salinity, hardness, fluoride, arsenic, or harmful pathogens which cause several health problems.

Water being a universal solvent has been and is being utilized by man kind time and now. Of the total amount of global water, only $2.4 \%$ is distributed on the main land, of which only a small portion can be utilized as fresh water. The available fresh water to man is hardly $0.3 \%$ $0.5 \%$ of the total water available on the earth and therefore, its judicious use is imperative [1]. The fresh water is a finite and limited resource [2]. The utilization of wa-

${ }^{*}$ Corresponding author. ter from ages has led to its over exploitation coupled with the growing population along with improved standard of living as a consequence of technological innovations [3, 4]. This contamination of groundwater is not away from the evils of modernization. Therefore, quality of groundwater is deteriorating at a faster pace due to pollution ranging from septic tanks $[5,6]$, land fill leachates, domestic sewage [7-9], agricultural runoff/agricultural fields [10-14] and industrial wastes $[3,4,8,15]$. Contamination of groundwater also depends on the geology of the area and it is rapid in hard rock areas especially in limestone regions where extensive cavern systems are below the water table [16]. This is a common feature, not only in developed countries but also in developing countries like India. The changes in quality of groundwater response to variation in physical, chemical and biological environments through which it passes [17].

Groundwater is normally used directly in rural areas 
without proper monitoring and treatment. Groundwater may also become contaminated by the agrochemical products used for irrigation. The groundwater quality in southern part of the country namely Chennai, Kancheepuram and Chengalpet, has been studied earlier [18-23]. However, no such studies have been carried out in the Dwarakeswar watershed region of West Bengal, pertaining to groundwater quality. The suitability of groundwater for domestic and irrigation purposes thus had to be determined based on the presence of major ions in the groundwater of this region. The present study, which was carried out in 2009, will serve as baseline data for comparing future groundwater quality.

\section{Study Area}

The study area comprises of Precambrian crystalline and recently deposited alluvium connected by an intervening tract. The Dwarkeswar watershed with a semi-elliptical shape occupies the Kashipur block which is situated in northeastern part of Puruliya district, but the major part of the Dwarkeswar watershed is situated in a part of Chhatna block of Bankura district of West Bengal state, India.

The Dwarkeswar watershed is bounded by longitudes $86^{\circ} 51^{\prime} \mathrm{E}$ and $87^{\circ} 0^{\prime} \mathrm{E}$ and latitudes $23^{\circ} 16^{\prime} \mathrm{N}$ to $23^{\circ} 50^{\prime} \mathrm{N}$. and is covered in the Survey of India Toposheet numbers 73 $\mathrm{I} / 11,73 \mathrm{I} / 15$ and $73 \mathrm{I} / 16$ on 1:50,000 scale The Dwarkeswar watershed lies in between the Damodar basin (to the north) and Kangsabati basin (to the south). The Dwarkeswar river is one of them largest river which rises in the hilly terrain of Puruliya district and flows from northwest to south east, almost dividing the Chhatna Block into two equal halves. The Dwarkeswar flows east up to Kashipur and then South east from $86^{\circ} 44^{\prime}$ E. where it receives the Bekon Nala flowing east-south east. The other left bank tributary Dangra Nala has scissored the undulating surface into mesh of gully before entering the Bankura district as the Kumari Nala. The right bank tributaries of the Dwarkeswar river are the Futuari Nala flowing north east, Dudhbhaiya Nala flowing north and Arkasa Nala flowing east the last two having their sources near Hura block. The Arkasa turn north east in Bankura district where from its confluence, the Dwarkeswar River becomes a perennial stream. Dwarkeswar river and all above mentioned tributaries dry up during the cold and hot seasons. Gully erosion all along their channels is a very conspicuous feature. In its lower course the Dwarkeswar river is known as Rupnarayan.

\section{Materials and Methods}

Groundwater samples were collected in polythene bottles of 2 liters capacity for physicochemical analysis after pumping out sufficient quantity of water from the tub- ewells such that, the sample collected served as a representative sample. The sample locations are shown in Figure 1. The bottles were completely filled before sealing tightly. All particulars regarding water sample were written in the field itself, immediately after sampling, and tagged to the sample bottle. Special treatment are given for preservation, fixation and handling of water samples before analysis so that the quality of water is not changed and many of heavy metal ions normally present in small quantities in natural water remain in water till the sample is analyzed. High temperature is avoided in the storage room. Only high pure (Analytical IR Grade) chemicals and double-distilled water was used for preparing solutions for analysis. Physical parameters like $\mathrm{pH}$, Electrical Conductivity (EC), Total Dissolved Solids (TDS) were determined at the site with the help of field kit.

The groundwater quality was assessed by the analysis of chemical parameters such as chlorides sulphates, bicarbonates, iron, calcium, magnesium and sodium using standard methods [24]. The results of the physicochemical parameters of the samples are shown in Table 1.

\section{Results and Discussions}

\subsection{Hydrogeology}

Hard rocks are mainly composed of metamorphic and magmatic rocks of Precambrian or Archean ages. The importance of hard rock aquifers from groundwater point of view differs from place to place, depending on various factors, but mainly on the overall availability and demand of water. Hard rock aquifers generally occupy the upper tens of meters of the subsurface profile [25]. The hydrogeologi cal characteristics of the weathered mantle and underlying bedrock depend mainly on the weathering and erosional processes [26,27].

Hydrogeological studies reveal that ground water occurs in two distinct group of aquifers - the upper one is weathered residuum of mica-schists and associated rocks, restricted within 10 to $15 \mathrm{~m}$ below ground level and deeper

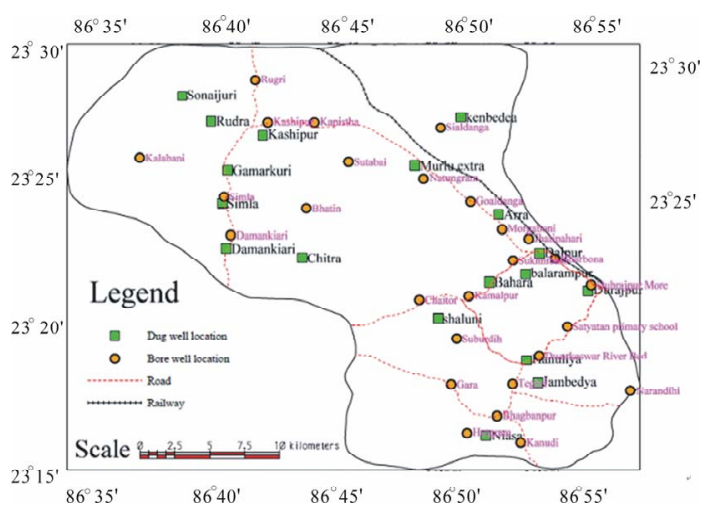

Figure 1. Map of the study area showing sample locations. 
Table 1. Report of physico-chemical parameters of the studied groundwater samples (pre-monsoon and post-monsoon, 2009).

\begin{tabular}{|c|c|c|c|c|c|c|c|c|c|c|c|c|c|c|c|c|c|c|c|c|}
\hline \multirow{3}{*}{$\begin{array}{c}\text { Sample } \\
\text { No. }\end{array}$} & \multirow{3}{*}{$\begin{array}{l}\text { Location } \\
\text { Name }\end{array}$} & \multirow{2}{*}{\multicolumn{8}{|c|}{ Physical Parameters }} & \multicolumn{11}{|c|}{ Chemical Parameters } \\
\hline & & & & & & & & & & & & & nions & & & & & Cations & & \\
\hline & & pre & post & pre & post & pre & post & pre & post & pre & post & pre & post & pre & post & pre & post & $\begin{array}{c}\begin{array}{c}\mathrm{Mg} \\
(\mathrm{mg} / \mathrm{L})\end{array} \\
\text { pre post }\end{array}$ & post & pre post \\
\hline A2 & $\begin{array}{l}\text { Satyatan } \\
\text { p.school }\end{array}$ & 7.7 & 7.1 & 190 & 300 & 122 & 122 & 100 & 130 & 40 & 40 & 110 & 170 & 47.5 & 76.3 & 0.50 & 0.8 & 3.924 .839 .98 & 59.94 & $6.37 \quad 5.21$ \\
\hline A3 & $\begin{array}{c}\text { Dwarkeswar } \\
\text { R. Bed }\end{array}$ & 7.9 & 6.4 & 180 & 400 & 115 & 122 & 90 & 1070 & 20 & 30 & 110 & 170 & 12.2 & 42.9 & 0.10 & 0.4 & 4.204 .1814 .40 & 46.43 & 6.573 .72 \\
\hline A4 & Teghri & 6.7 & 6.6 & 1850 & 3400 & 1184 & 1365 & 1030 & 750 & 640 & 580 & 180 & 280 & 53.7 & 76.4 & 0.50 & 0.8 & 5.204 .7153 .74 & 113.24 & 11.474 .16 \\
\hline A6 & Suburdih & 6.4 & 6.5 & 130 & 300 & 83 & 130 & 90 & 330 & 40 & 110 & 130 & 190 & 41.6 & 116.5 & 0.50 & 1.2 & 3.343 .516 .39 & 79.96 & 5.354 .07 \\
\hline A7 & Kamalpur & 7.0 & 7.0 & 480 & 900 & 307 & 334 & 280 & 200 & 30 & 40 & 430 & 350 & 127.8 & 138.4 & 3.00 & 3.0 & 4.813 .7121 .61 & 40.06 & 6.994 .59 \\
\hline A8 & Sukhnibash & 6.1 & 6.4 & 450 & 900 & 288 & 333 & 200 & 310 & 90 & 110 & 140 & 150 & 153.1 & 43.5 & 3.00 & 0.5 & 4.393 .6218 .19 & 36.53 & 10.017 .83 \\
\hline A9 & Jhatipahari & 6.1 & 6.4 & 590 & 400 & 378 & 327 & 350 & 210 & 110 & 100 & 150 & 230 & 98.5 & 21.6 & 3.00 & 0.2 & 4.873 .7824 .02 & 30.07 & $8.10 \quad 6.87$ \\
\hline A10 & Morgaboni & 6.3 & 6.5 & 220 & 500 & 141 & 177 & 140 & 210 & 20 & 50 & 160 & 230 & 26.3 & 25.9 & 0.30 & 0.2 & 4.213 .6712 .41 & 84.57 & $6.57 \quad 5.71$ \\
\hline A11 & Kharbona & 7.5 & 6.6 & 590 & 1300 & 378 & 495 & 400 & 420 & 80 & 110 & 780 & 350 & 37.2 & 28.5 & 0.30 & 0.3 & 4.714 .1330 .84 & 59.96 & $9.34 \quad 7.52$ \\
\hline A12 & Narandihi & 7.2 & 7.1 & 460 & 800 & 294 & 360 & 240 & 270 & 70 & 50 & 240 & 250 & 86.7 & 27.4 & 0.80 & 0.2 & 4.693 .4123 .69 & 74.86 & 6.616 .32 \\
\hline A13 & Kanudi & 6.5 & 6.5 & 170 & 300 & 109 & 104 & 90 & 150 & 10 & 40 & 130 & 180 & 152.4 & 31.5 & 1.20 & 0.3 & 4.324 .818 .09 & 79.53 & 5.237 .26 \\
\hline A14 & Bhagbanpur & 7.1 & 7.1 & 220 & 400 & 141 & 144 & 110 & 200 & 20 & 20 & 120 & 170 & 23.6 & 27.5 & 0.30 & 2.0 & 4.244 .8310 .68 & 103.27 & $5.22 \quad 5.02$ \\
\hline A16 & Chaitor & 6.9 & 6.9 & 780 & 1100 & 499 & 442 & 460 & 430 & 160 & 120 & 250 & 290 & 42.2 & 11.6 & 0.50 & 0.3 & 4.813 .7944 .29 & 43.76 & 6.996 .52 \\
\hline A17 & Goaldanga & 7.4 & 6.4 & 880 & 1500 & 563 & 542 & 460 & 450 & 220 & 200 & 160 & 170 & 59.4 & 24.7 & 0.50 & 0.3 & 4.853 .9241 .06 & 36.29 & $8.65 \quad 5.74$ \\
\hline A18 & Kalabani & 6.6 & 6.8 & 350 & 200 & 1340 & 92 & 1010 & 190 & 570 & 30 & 290 & 180 & 73.6 & 35.7 & 0.70 & 0.1 & 4.962 .07110 .64 & 443.87 & 3.941 .04 \\
\hline A19 & Damankiari & 6.4 & 6.6 & 130 & 900 & 438 & 325 & 380 & 330 & 90 & 90 & 140 & 210 & 36.3 & 39.6 & 0.30 & 3 & 3.763 .5236 .42 & 73.65 & 3.583 .68 \\
\hline $\mathrm{A} 20$ & Simla & 6.8 & 6.4 & 120 & 1600 & 447 & 633 & 470 & 460 & 127 & 310 & 310 & 230 & 43.1 & 28.5 & 0.40 & 1.2 & 4.132 .1646 .73 & 68.27 & 3.975 .83 \\
\hline $\mathrm{A} 21$ & Kashipur & 6.6 & 6.2 & 160 & 800 & 540 & 283 & 490 & 260 & 220 & 110 & 190 & 180 & 16.3 .3 & 21.6 & 0.20 & 1.2 & 4.762 .2338 .79 & 53.94 & 8.374 .39 \\
\hline $\mathrm{A} 22$ & Rugri & 6.6 & 6.9 & 210 & 1700 & 1154 & 622 & 982 & 660 & 360 & 250 & 350 & 330 & 56.8 & 24.73 & 0.76 & 1.2 & 2.862 .3894 .68 & 57.73 & 5.276 .84 \\
\hline A23 & Kapistha & 6.5 & 6.9 & 280 & 200 & 30 & 94 & 160 & 120 & 310 & 30 & 320 & 140 & 112.7 & 20.05 & 0.80 & 0.1 & 3.721 .9379 .37 & 53.26 & 3.946 .38 \\
\hline $\mathrm{A} 24$ & Bhatin & 6.9 & 6.6 & 207 & 1500 & 376 & 574 & 385 & 500 & 170 & 170 & 340 & 210 & 36.3 & 22.73 & 0.30 & 1.2 & 3.842 .3458 .69 & 41.37 & 5.824 .72 \\
\hline A 25 & Sutabai & 6.7 & 6.6 & 210 & 1800 & 174 & 721 & 480 & 500 & 140 & 250 & 280 & 180 & 18.7 & 17.63 & 0.30 & 0.5 & 4.863 .26114 .37 & 768.38 & 5.865 .96 \\
\hline A26 & Natungram & 7.2 & 6.8 & 50 & 900 & 36 & 353 & 140 & 220 & 62 & 90 & 130 & 280 & 163.9 & 46.38 & 2.07 & 0.4 & 4.873 .1778 .41 & 61.94 & 6.483 .46 \\
\hline A 27 & Sialdanga & 7.1 & 6.4 & 40 & 2500 & 148 & 1008 & 130 & 800 & 68 & 400 & 130 & 390 & 183 & 29.7 & 2.04 & 0.2 & 4.962 .0678 .41 & 52.17 & 6.485 .29 \\
\hline
\end{tabular}

one represented by fractures occurring at varying depth between $30 \mathrm{~m}$ to $150 \mathrm{~m}$ below ground level. Both the aquifers are the repositories of ground water within secondary porosities developed due to geological process. The first aquifers is developed by due wells and solely used for drinking and other domestic purposes. The second aquifer (fracture zones) being exploited for industrial water supply are also used for drinking water supply.

Ground water is hidden from view beneath the land surface, it can only be directly observed through monitoring wells. In order to assess water level configuration of different aquifers, hydrogeological studies have been carried out. The upper aquifer is tapped by open dug wells and mainly used for domestic consumption. Bore 
wells in different industries withdrawal water from the deeper fracture zones, which occurs under semi-confined to confined conditions.

Altogether 27 nos. of bore wells and 24 nos. of dug wells were marked and monitored for having an idea of water table in pre- and post-monsoon 2009 (Figure 2). Water table studies indicate that groundwater level varies in between $95.94 \mathrm{mts}$ to $193.17 \mathrm{mts}$. in pre-monsoon. Highest value of water table is recorded in Damankiari area. In post-monsoon water table studies indicate that groundwater level varies in between $98.41 \mathrm{~m}$ to $195.70 \mathrm{~m}$. Highest value of water table is recorded in Kalabani area (Figures 2(a) and (b)).

In case of dug well water table varies between 105.05 $\mathrm{mts}$ to $193.88 \mathrm{mts}$ in pre-monsoon and in post-monsoon it varies between $108.25 \mathrm{mts}$ to $196.88 \mathrm{mts}$. Lowest value of water table is recorded in Hanuliya area $105.5 \mathrm{mts}$ and $108.25 \mathrm{mts}$ during pre-and post-monsoon respectively. Water table contour map of dug well indicates the for-

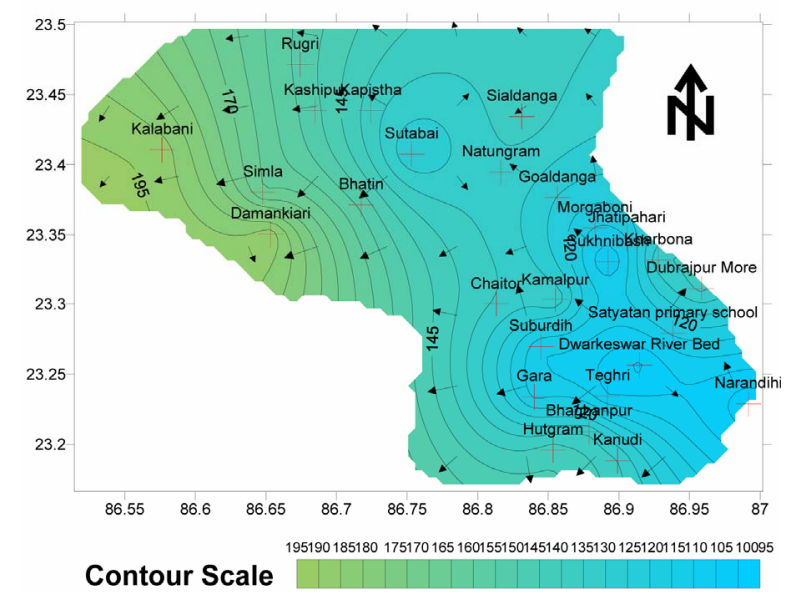

(a)

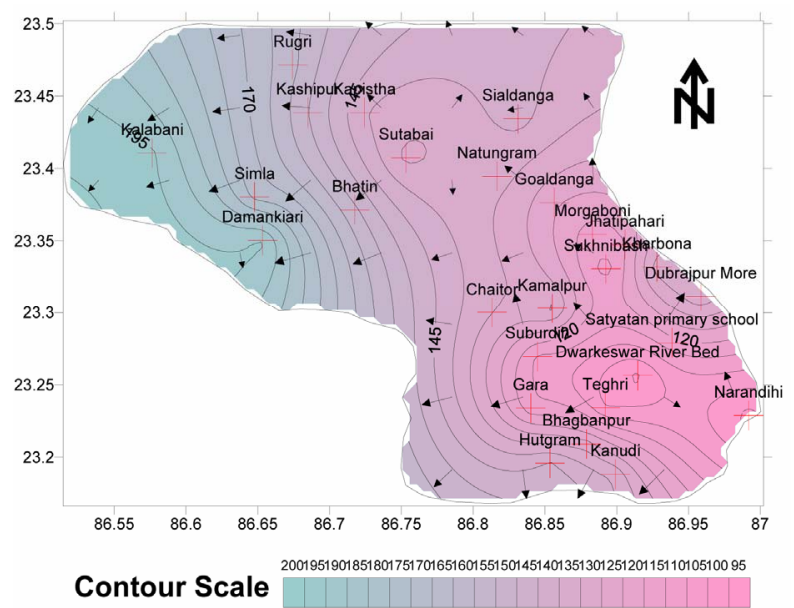

(b)

Figure 2. Water table contour map of the study area bore well: (a) pre-monsoon; (b) post-monsoon. mation of a cone of depression in the area surrounding Teghori and Jambani in pre- and post-monsoon time (Figures 3(a) and (b))

\subsection{Major Ion Chemistry and Spatial Distribution}

The $\mathrm{pH}$ values of the groundwater varied from 6.1 to 7.9 with an average value 6.9 (pre-monsoon) while the $\mathrm{pH}$ values range between 6.2 to 7.1 (post-monsoon) with an average value 6.7. This indicates that water is neutral in nature. The variation in $\mathrm{pH}$ values both in pre- and postmonsoon periods are shown in Figures 4(a) and (b).

In the study area, the value of electrical conductivity varied from $40-1940 \mu \mathrm{S} / \mathrm{cm}$ with an average value of $423.96 \mu \mathrm{S} / \mathrm{cm}$ during pre-monsoon while the value ranged between $200-3400 \mu \mathrm{S} / \mathrm{cm}$ with an average of 1040.74 $\mu \mathrm{S} / \mathrm{cm}$ during post-monsoon period (Figures 5(a) and (b)).

In the study area, the concentration value of TDS

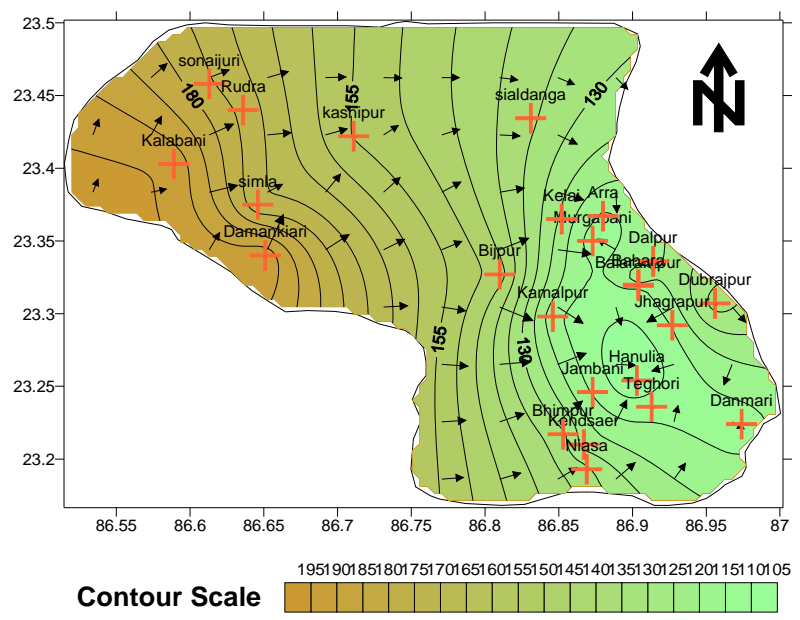

(a)

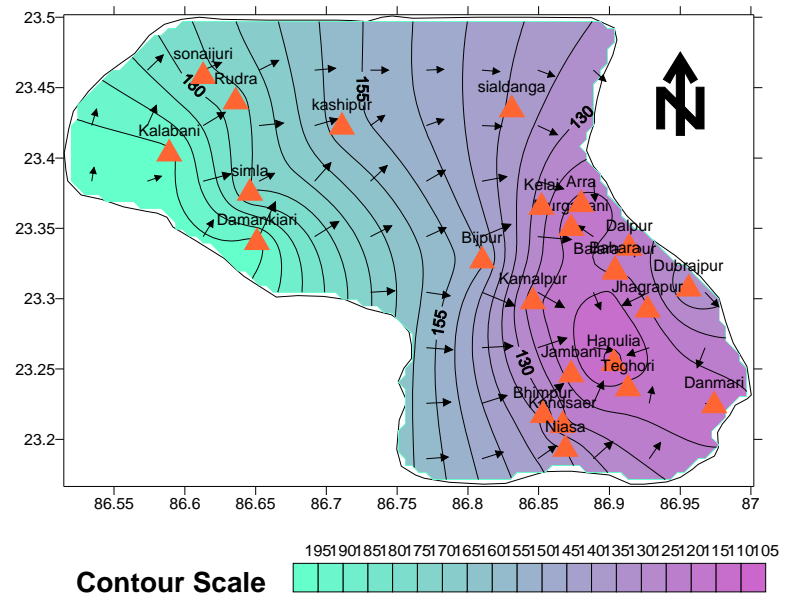

(b)

Figure 3. Water table contour map of the study area dug well: (a) pre-monsoon; (b) post-monsoon. 
ranged between 30 to $1340 \mathrm{mg} / \mathrm{L}$ (pre-monsoon) with the mean value of $403.18 \mathrm{mg} / \mathrm{L}$. The TDS value ranged between 92 to $1365 \mathrm{mg} / \mathrm{L}$ (post-monsoon) with the mean value of $409.63 \mathrm{mg} / \mathrm{L}$. The TDS of the study area falls within the WHO (2004) Standard of $1000 \mathrm{mg} / \mathrm{L}$. The water is thus good for human consumption (domestic) and agricultural purposes (Figures 6(a) and (b)).

The total hardness expressed as $\mathrm{CaCO}_{3}$ is above the desirable limit $(300 \mathrm{mg} / \mathrm{L})$ and allowable limit is $(600$ $\mathrm{mg} / \mathrm{L})$. The hardness is temporary in nature and can be removed by boiling. The water samples of the study area show variation from $90-1190 \mathrm{mg} / \mathrm{L}$ (pre-monsoon) with an average value of $376.55 \mathrm{mg} / \mathrm{L}$ while the value of hardness ranged between $120-1070 \mathrm{mg} / \mathrm{L}$ during postmonsoon period with the average value of $360.74 \mathrm{mg} / \mathrm{L}$ (Figures 7(a) and (b))

The hardness in water is derived from the solution of carbon dioxide released by bacterial action in the soil, in percolating rain water. Low $\mathrm{pH}$ conditions develop and lead to the dissolution of insoluble carbonates in the soil and in limestone formations to convert them into soluble

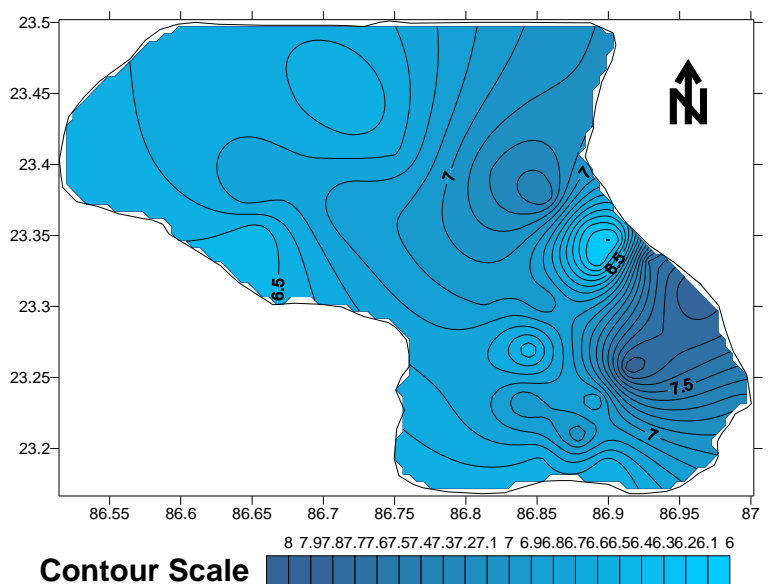

(a)

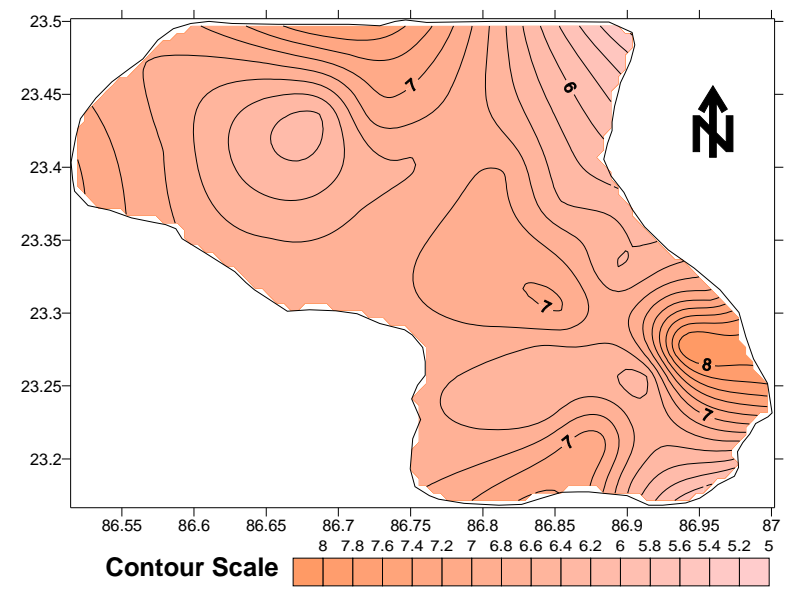

(b)

Figure 4. pH contour map: (a) pre-monsoon; (b) post-monsoon. bicarbonates. Impurities in limestone, such as sulfates, chlorides and silicates, become exposed to the solvent action of water as the carbonates are dissolved so that they also pass into solution. The general acceptance level of hardness is $300 \mathrm{mg} / \mathrm{L}$, although WHO [23] has set an allowable limit of $600 \mathrm{mg} / \mathrm{L}$. The spatial distribution pattern of physical parameters like $\mathrm{pH}$, Electrical Conductivity (EC), Total Dissolved Solids (TDS) during the study period are shown in Figures 4(a) and (b), Figures 5(a) and (b) and Figures 6(a) and (b).

In the study area, the concentration of chloride is found to vary between $10-660 \mathrm{mg} / \mathrm{L}$ with the average value of $163.2 \mathrm{mg} / \mathrm{L}$ in pre-monsoon while during postmonsoon the value ranged between 20 - $580 \mathrm{mg} / \mathrm{L}$ with the mean value of $139.3 \mathrm{mg} / \mathrm{L}$ (Figures 8(a) and (b)). The mean values during pre- and post-monsoon time are much below the maximum allowable concentration of $250 \mathrm{mg} / \mathrm{L}$ [28]. WHO has set standards of $200-500 \mathrm{mg} / \mathrm{L}$ for chloride in drinking water. Too much of chloride leads to bad taste in water and also chloride ion combines with the $\mathrm{Na}$ (that is being derived from the weathering of

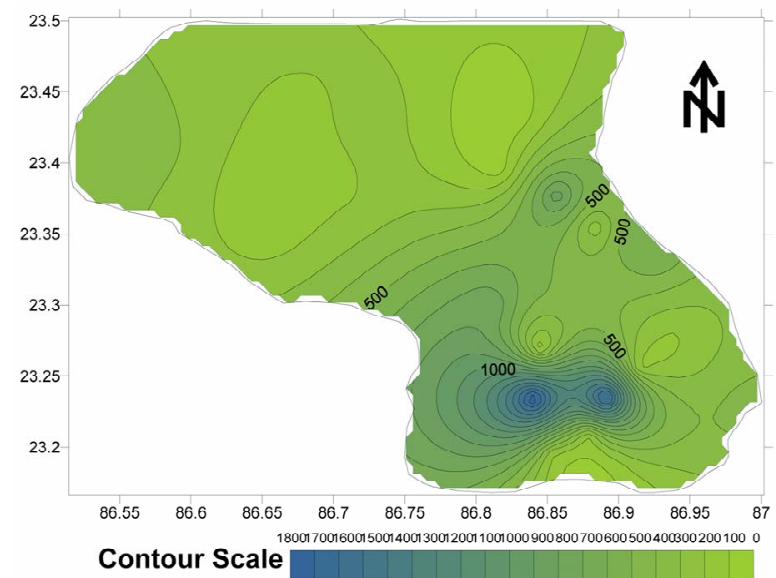

(a)

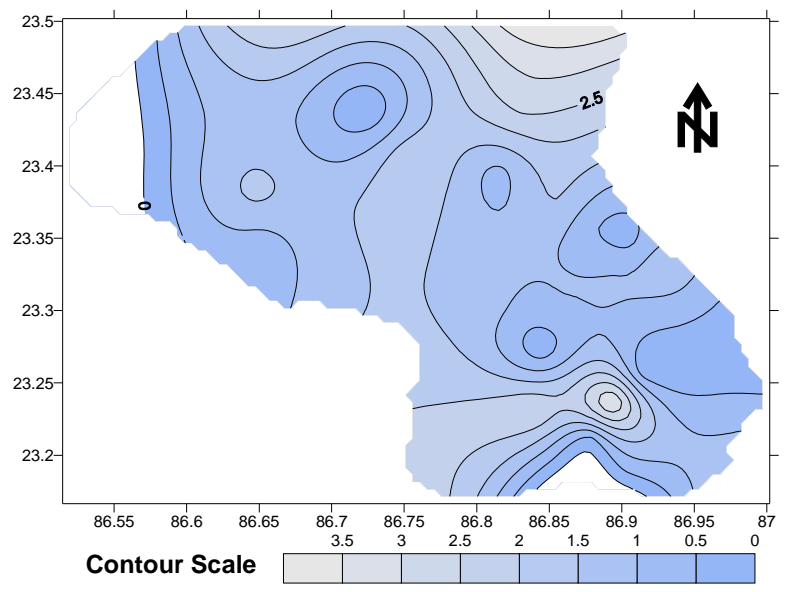

(b)

Figure 5. Specific conductivity contour map: (a) pre-monsoon; (b) post-monsoon. 


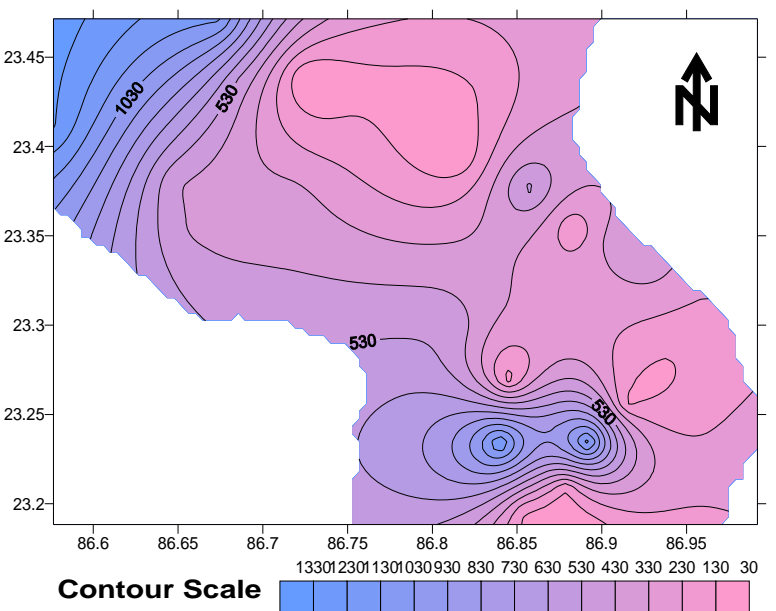

(a)

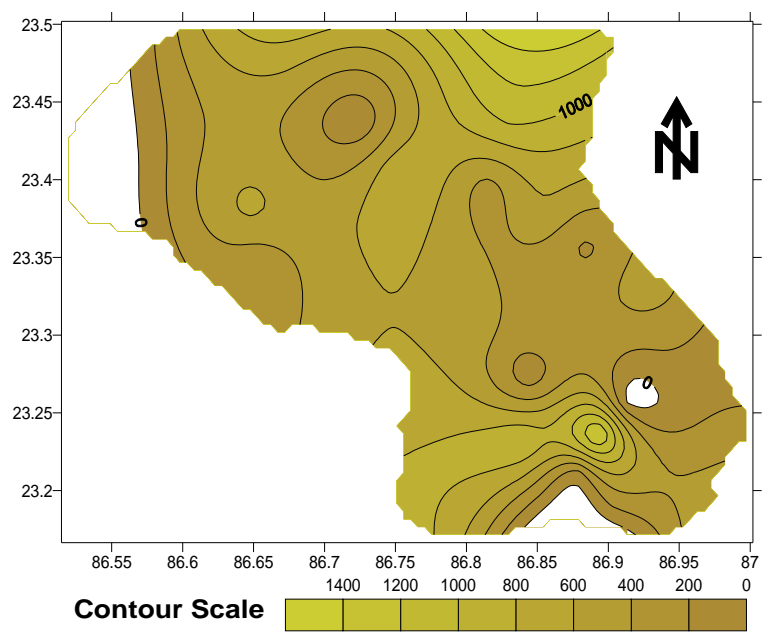

(b)

Figure 6. Total dissolved solids contour map: (a) pre-monsoon; (b) post-monsoon.

granitic terrains) and forms $\mathrm{NaCl}$, whose excess presence in water makes it saline and unfit for drinking and irrigation purposes. Here too, as exhibited by contours, the chloride value decreases during post-monsoon.

Bicarbonate ion varied from 110 to 780 and with mean value of $229.6 \mathrm{mg} / \mathrm{L}$ during pre-monsoon and 140 to 390 $\mathrm{mg} / \mathrm{L}$ with average value of $231.5 \mathrm{mg} / \mathrm{L}$ in the groundwater samples of post-monsoon season period (Figures 9(a) and (b)).

The sulfate ion causes no particular harmful effects on soils or plants; however, it contributes to increase the salinity in the soil solution. Sulphur is an essential element in plant nutrition and in the form of sulphate it is readily available to plants. Sulfate ion varied from 12.2 to $183.0 \mathrm{mg} / \mathrm{L}$ during the pre-monsoon and from 11.6 to $138.4 \mathrm{mg} / \mathrm{L}$ in post-monsoon seasons (Figures 10(a) and (b)).

Calcium and magnesium ions present in groundwater

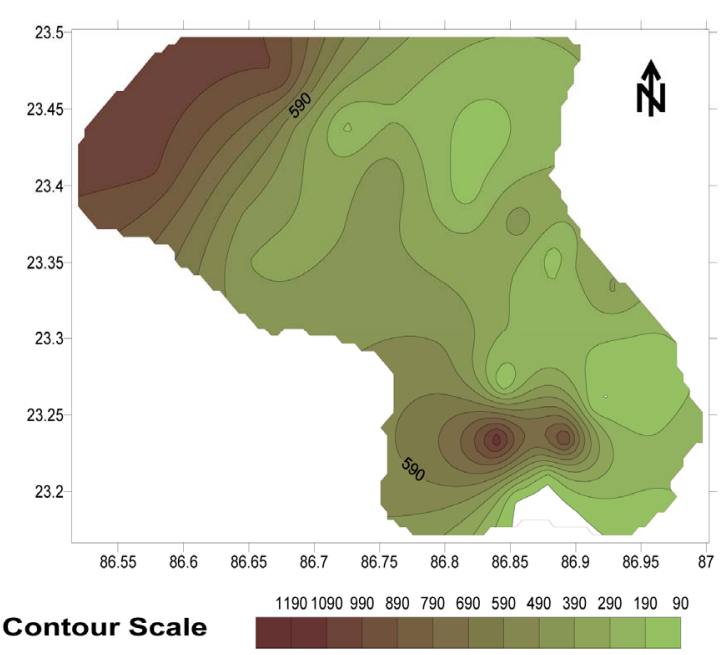

(a)

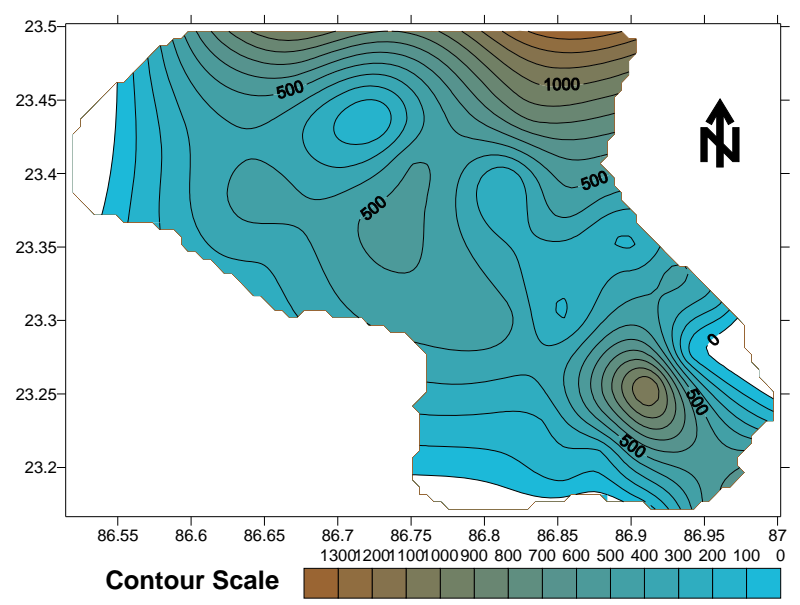

(b)

Figure 7. Hardness contour map: (a) pre-monsoon; (b) postmonsoon.

of nearby coastal areas are derived from leaching of limestone, dolomite, gypsum and anhydrites whereas calcium ions may derive from cation exchange processes [29]. Calcium in normal potable ground water has concentration between 10 and 100 ppm which has no known effect on the health of human or animals. In the present study, the concentration of Calcium ranged from 6.39 to $114.37 \mathrm{mg} / \mathrm{L}$ during pre-monsoon while it varied from 30.06 to $214.23 \mathrm{mg} / \mathrm{L}$ during post-monsoon periods. The spatial distribution of calcium during the study period is shown in Figures 11(a) and (b).

In the present study, the concentration of Magnesium ranged from 2.86 to $5.2 \mathrm{mg} / \mathrm{L}$ during pre-monsoon while it varied from 1.93 to $4.88 \mathrm{mg} / \mathrm{L}$ during post-monsoon periods (Figures 12(a) and (b)).

The adverse effect of sodium on the soil was more closely related to the ratio of sodium to the total cations in the irrigation water than to the absolute concentration 


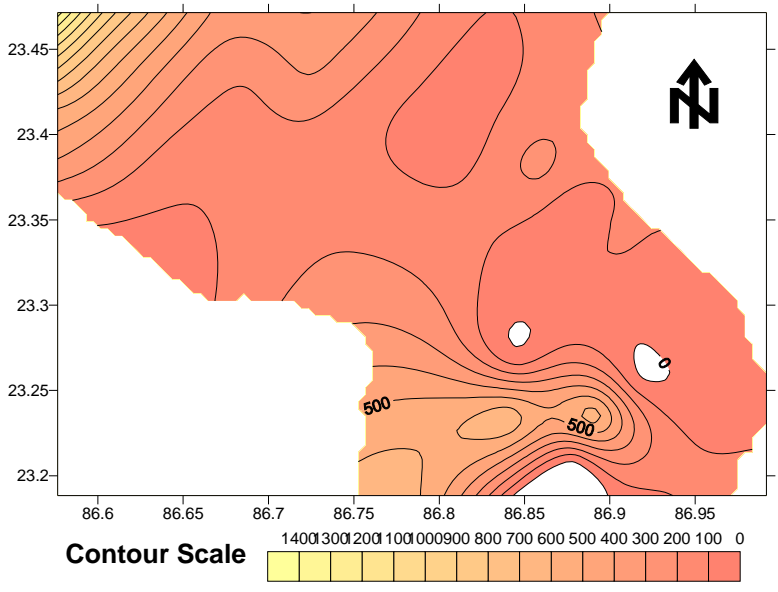

(a)

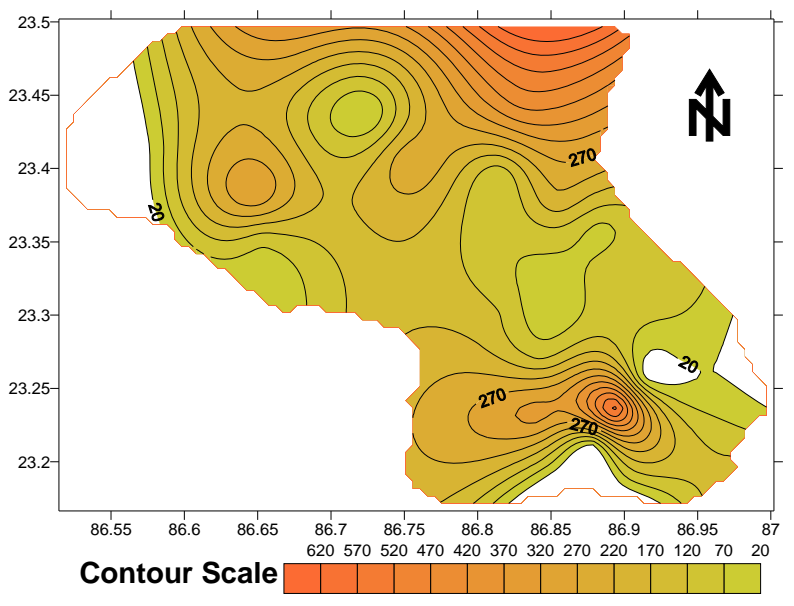

(b)

Figure 8. Chloride contour map: (a) pre-monsoon; (b) post-monsoon.

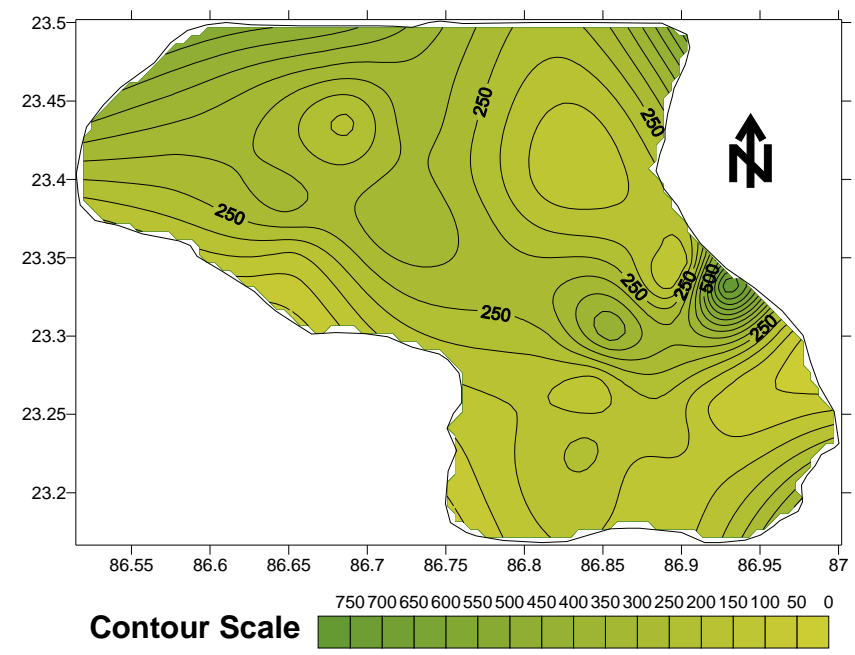

(a)

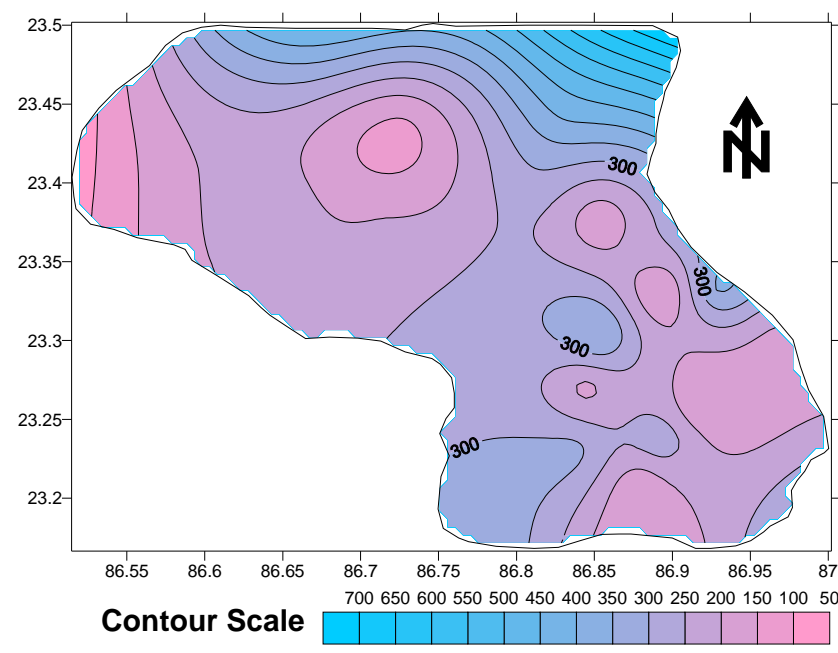

(b)

Figure 9. Bi-carbonate contour map: (a) pre-monsoon; (b) post-monsoon.

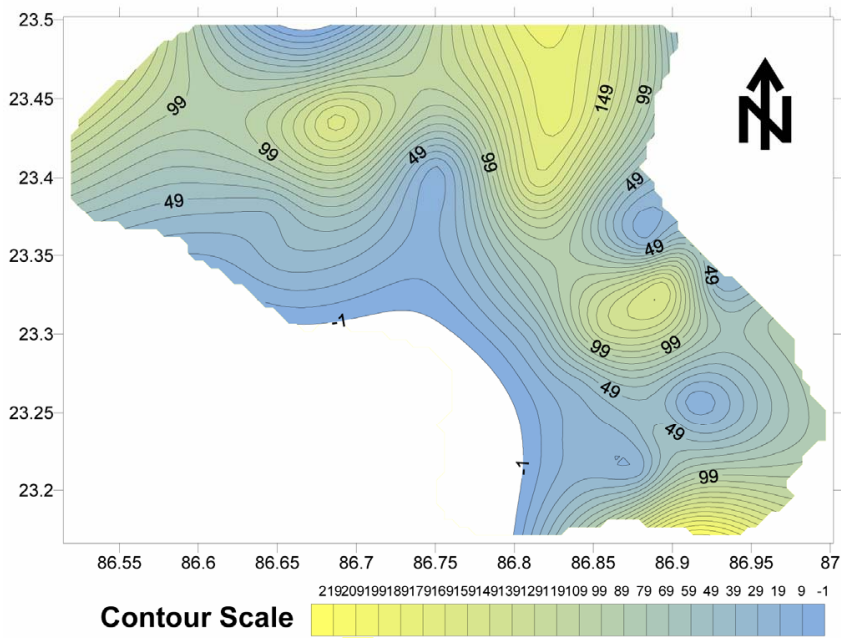

(a)

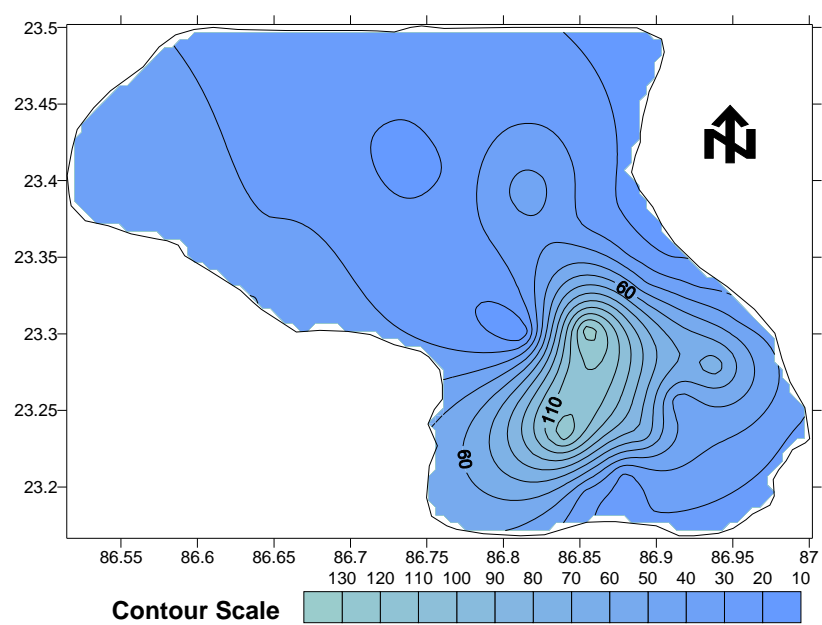

(b)

Figure 10. Sulphate contour map: (a) pre-monsoon; (b) post-monsoon. 
of sodium. It has now been recognized that as percent of sodium increases in the soil solution larger quantities are absorbed during the exchange, replacing calcium and magnesium, thus resulting in alkali soil. The concentration of sodium in the water samples collected vary from 3.58 to $11.57 \mathrm{mg} / \mathrm{L}$ (pre-monsoon) and 1.04 to 7.83 $\mathrm{mg} / \mathrm{L}$ (post-monsoon) (Figures 13(a) and (b)).

Iron is an essential element in human [30]. Although iron has little concern as a health hazard, it is still considered as a nuisance in excessive quantities [31]. It causes staining of clothes and utensils. It is also not suitable for processing of food, beverages, dyeing, bleaching etc. The concentration limits of iron in drinking water ranges between $0.3 \mathrm{mg} / \mathrm{L}$ (maximum acceptable) and 1.0 $\mathrm{mg} / \mathrm{L}$ (maximum allowable) (Figures 14(a) and (b)). The concentration of iron in the water samples collected vary from 0.1 to $3.0 \mathrm{mg} / \mathrm{L}$ both in pre- and post-monsoon.

During pre-monsoon, most of the ion concentrations are high compared to the post-monsoon period and this may be due to the dissolution of minerals $[32,33]$.

\subsection{Irrigational Suitability}

Water for agricultural purposes should be good for both plant and animals. Good quality of waters for irrigation is characterized by acceptable range of:

1) The Sodium Adsorption Ratio (SAR);

2) The Soluble Sodium Percentage (SSP);

3) The Residual Sodium Carbonate (RSC);

4) The Magnesium Adsorption Ratio (MAR);

5) The Kellys Ratio (KR);

6) The Permeability Index (PI).

All these parameters are calculated and are presented in Table 2.

The Sodium Adsorption Ratio (SAR) was calculated by the following equation given by Richards [34] as:

$$
\mathrm{SAR}=\frac{\mathrm{Na}}{\sqrt{\frac{\mathrm{Ca}+\mathrm{Mg}}{2}}}
$$

where, all the ions are expressed in meq/L.

Sodium Adsorption Ratio (SAR) also influences infiltration rate of water. So, low SAR is always desirable. In the studied samples, SAR values were ranged between $0.09-0.54 \mathrm{meq} / \mathrm{L}$ in pre monsoon and $0.01-0.24$ in postmonsoon. It is evident from the whole sample set that the SAR value is excellent in all the samples. (Figure 15) Hence, our findings strongly suggest that all the abstracted groundwater samples from the study area were suitable for irrigation.

The Soluble Sodium Percentage (SSP) was calculated by the following equation Todd [35]:

$$
\mathrm{SSP}=\frac{(\mathrm{Na}+\mathrm{K}) \times 100}{(\mathrm{Ca}+\mathrm{Mg}+\mathrm{Na}+\mathrm{K})}
$$

where, all the ions are expressed in meq/L. Wilcox [36] has developed a table for classification of irrigation water with reference to Na percentage and EC value (umhos/cm) (Figure 16).The Soluble Sodium Percentage (SSP) values were found from $2.78 \mathrm{meq} / \mathrm{L}$ at Kalabani to $28.01 \mathrm{meq} / \mathrm{L}$ at Suburdih in pre monsoon and $1.52 \mathrm{meq} / \mathrm{L}$ at Gara and $13.82 \mathrm{meq} / \mathrm{L}$ at Sukhnibash in post monsoon.

The Residual Sodium Carbonate (RSC) was calculated according to Gupta and Gupta [37]:

$$
\mathrm{RSC}=\left(\mathrm{CO}_{3}+\mathrm{HCO}_{3}\right)-(\mathrm{Ca}+\mathrm{Mg})
$$

where, RSC and the concentration of the constituents are expressed in meq/L. The Residual Sodium Carbonate (RSC) values were found from $-2.2 \mathrm{meq} / \mathrm{L}$ at Sialdanga $5.57 \mathrm{meq} / \mathrm{L}$ at Kamalpur in pre-monsoon and -7.67 $\mathrm{meq} / \mathrm{L}$ at Gara and $3.62 \mathrm{meq} / \mathrm{L}$ at Sukhnibash in post monsoon.

Total Hardness $(\mathrm{TH})$ was calculated by the following equation Raghunath [38]:

$$
\mathrm{TH}=(\mathrm{Ca}+\mathrm{Mg}) \times 50
$$

where, $\mathrm{TH}$ is expressed in meq/L and the concentrations of the constituents are expressed in meq/L. Total Hardness (TH) values were found from $29.89 \mathrm{meq} / \mathrm{L}$ at Suburdih $297 \mathrm{meq} / \mathrm{L}$ at Kalabani in pre-monsoon and $83.5 \mathrm{meq} / \mathrm{L}$ at Dubrajpur $555.5 \mathrm{meq} / \mathrm{L}$ at Hutgram in post-monsoon.

Magnesium Adsorption Ratio (MAR) was calculated by the equation Raghunath [38] as:

$$
\mathrm{MAR}=\mathrm{Mg} \times 100 /(\mathrm{Ca}+\mathrm{Mg})
$$

where all the ionic concentrations are expressed in $\mathrm{meq} / \mathrm{L}$. Magnesium Adsorption Ratio (MAR) values were found from 4.63 at Rugri 47.09 at Kanudi in pre-monsoon and 3.60 at Hutgram and 17.12 at Jhatipahari in post-monsoon.

The Kelly's Ratio was calculated using the equation Kelly [39] as:

$$
\mathrm{KR}=\mathrm{Na} /(\mathrm{Ca}+\mathrm{Mg})
$$

where, all the ionic concentrations are expressed in meq/L. The Kelly's Ratio (KR) values were found from 0.02 at Kalabani 0.34 at Sukhnibash in pre-monsoon and 0.01 at Kalabani,Gara 0.16 at Jhatipahari in post-monsoon.

\section{Permeability Index}

Doneen [40] has evolved a modified criterion based on the solubility of salts and the reaction occurring in the soil solution from cation exchange for estimating the quality of agricultural waters. According to him, soil permeability, as affected by long-term use of irrigation water, is influenced by 1) total dissolvesolid 2) sodium contents, 3) bicarbonate contents, and the soil. To incorporate the first three items Doneen [40] has empirically developed a term called, "Permeability Index" after conducting a series of experiments for which he has used 
Table 2. Resulting parameters (pre-monsoon and post-monsoon, 2009) of the studied groundwater samples.

\begin{tabular}{|c|c|c|c|c|c|c|c|c|c|c|c|c|c|c|c|}
\hline \multirow{2}{*}{$\begin{array}{c}\text { Sample } \\
\text { No. }\end{array}$} & \multirow{2}{*}{ Location Name } & \multicolumn{2}{|c|}{ SAR } & \multicolumn{2}{|c|}{ PI } & \multicolumn{2}{|c|}{ SSP } & \multicolumn{2}{|c|}{ MAR } & \multicolumn{2}{|c|}{$\mathrm{TH}$} & \multicolumn{2}{|c|}{ RSC } & \multicolumn{2}{|c|}{$\mathrm{KR}$} \\
\hline & & pre & post & pre & post & pre & post & pre & post & pre & post & pre & post & pre & post \\
\hline $\mathrm{A} 1$ & Dubrajpur More & 0.39 & 0.05 & 131.11 & 112.79 & 17.95 & 2.90 & 24.05 & 1.017 & 74.85 & 83.5 & 2.77 & 1.93 & 0.22 & 0.02 \\
\hline A2 & Satyatan p. school & 0.93 & 0.16 & 146.91 & 52.07 & 25.12 & 6.09 & 39.56 & 11.79 & 41.28 & 169.5 & 0.98 & -1.21 & 0.34 & 0.06 \\
\hline $\mathrm{A} 3$ & Warkeswar R. Bed & 0.38 & 0.13 & 120.13 & 64.53 & 21.07 & 5.67 & 32.71 & 12.78 & 53.50 & 133 & 0.73 & 0.12 & 0.27 & 0.06 \\
\hline A4 & Teghri & 0.39 & 0.1 & 61.25 & 37.23 & 13.78 & 2.88 & 13.89 & 6.44 & 156.02 & 302.5 & -0.17 & -1.46 & 0.16 & 0.02 \\
\hline A5 & Gara & 0.40 & 0.05 & 66.24 & 44.29 & 14.13 & 1.52 & 14.06 & 5.01 & 152.88 & 259 & 0.39 & -0.1 & 0.16 & 0.01 \\
\hline A6 & Suburdih & 0.43 & 0.11 & 203.8 & 43.37 & 28.01 & 3.40 & 46.56 & 6.77 & 29.89 & 214 & 1.53 & -1.17 & 0.39 & 0.03 \\
\hline A7 & Kamalpur & 0.24 & 0.01 & 165.74 & 103.61 & 17.02 & 7.63 & 27.06 & 13.04 & 74.07 & 115 & 5.57 & 3.43 & 0.21 & 0.08 \\
\hline A8 & Sukhnibash & 0.54 & 0.03 & 114.01 & 121.79 & 25.44 & 13.82 & 28.69 & 14.15 & 63.77 & 106 & 1.02 & 0.33 & 0.34 & 0.16 \\
\hline A9 & Jhatipahari & 0.39 & 0.3 & 98.02 & 105.23 & 17.98 & 13.80 & 25.26 & 17.12 & 80.34 & 90.5 & 0.85 & 1.96 & 0.22 & 0.16 \\
\hline A10 & Morgaboni & 0.40 & 0.16 & 151.57 & 45.79 & 22.73 & 5.04 & 36.12 & 6.63 & 48.57 & 226 & 1.65 & -0.75 & 0.29 & 0.05 \\
\hline A11 & Kharbona & 0.40 & 0.24 & 170.13 & 74.24 & 17.35 & 8.76 & 20.29 & 10.21 & 96.73 & 166.5 & 10.85 & 2.4 & 0.21 & 0.09 \\
\hline A 12 & Narandihi & 0.31 & 0.19 & 122.16 & 53.37 & 15.13 & 6.29 & 24.84 & 6.96 & 78.5 & 201 & 2.36 & 0.07 & 0.17 & 0.06 \\
\hline A13 & Kanudi & 0.36 & 0.21 & 170.1 & 43.16 & 22.93 & 6.62 & 47.09 & 9.15 & 38.23 & 218.5 & 1.37 & -1.42 & 0.30 & 0.07 \\
\hline A14 & Bhagbanpur & 0.33 & 0.12 & 146.24 & 32.4 & 20.73 & 3.63 & 39.82 & 7.19 & 44.37 & 278 & 1.08 & -2.78 & 0.26 & 0.03 \\
\hline A 15 & Hutgram & 0.42 & 0.13 & 136.33 & 18.98 & 24.27 & 2.79 & 45.35 & 3.60 & 44.10 & 555.5 & 1.74 & -7.67 & 0.32 & 0.02 \\
\hline A16 & Chaitor & 0.26 & 0.21 & 79.76 & 88.4 & 10.41 & 9.78 & 15.33 & 12.14 & 130.77 & 124.5 & 1.48 & 2.26 & 0.12 & 0.10 \\
\hline A17 & Goaldanga & 0.33 & 0.23 & 70.44 & 80.16 & 13.27 & 10.12 & 16.45 & 15.02 & 122.86 & 106.5 & 0.17 & 0.65 & 0.15 & 0.11 \\
\hline A18 & Kalabani & 0.09 & 0.03 & 38.29 & 72.91 & 2.78 & 1.66 & 6.90 & 7.20 & 297 & 118 & -1.19 & 0.59 & 0.02 & 0.01 \\
\hline A19 & Damankiari & 0.14 & 0.11 & 72.8 & 48.66 & 6.57 & 3.87 & 14.55 & 7.30 & 106.5 & 198.5 & 0.16 & -0.53 & 0.07 & 0.04 \\
\hline A20 & Simla & 0.14 & 0.18 & 85.21 & 57.03 & 5.98 & 6.51 & 12.73 & 5.01 & 133.5 & 179.5 & 2.41 & 0.9 & 0.06 & 0.06 \\
\hline $\mathrm{A} 21$ & Kashipur & 0.33 & 0.15 & 79.1 & 62.09 & 13.43 & 6.20 & 16.81 & 6.27 & 116 & 143.5 & 0.79 & 0.08 & 0.15 & 0.06 \\
\hline A22 & Rugri & 0.14 & 0.23 & 50.38 & 77.67 & 4.24 & 8.63 & 4.63 & 6.18 & 248 & 153.5 & 0.77 & 2.33 & 0.04 & 0.09 \\
\hline A23 & Kapistha & 0.11 & 0.22 & 55.18 & 57.6 & 3.82 & 8.73 & 7.25 & 5.67 & 213.5 & 141 & 0.97 & -0.78 & 0.03 & 0.09 \\
\hline A 24 & Bhatin & 0.19 & 0.18 & 74.57 & 83.67 & 7.14 & 8.16 & 9.84 & 8.44 & 162.5 & 112.5 & 2.32 & 1.19 & 0.07 & 0.08 \\
\hline A25 & Sutabai & 0.14 & 0.18 & 37.57 & 49.87 & 3.93 & 6.36 & 6.54 & 7.33 & 305.5 & 184 & -1.52 & 0.73 & 0.06 & 0.06 \\
\hline A26 & Natungram & 0.19 & 0.11 & 37.6 & 65.42 & 6.08 & 4.28 & 9.25 & 7.76 & 216 & 167.5 & -2.19 & 1.24 & 0.06 & 0.04 \\
\hline A27 & Sialdanga & 0.19 & 0.19 & 37.52 & 91.66 & 6.07 & 7.66 & 9.46 & 6.13 & 216.5 & 138.5 & -2.2 & 3.62 & 0.06 & 0.08 \\
\hline
\end{tabular}

Note: SAR—Sodium Absorption Ratio; PI—Permeability Index; SSP—Soluble Sodium Percentage; MAR—Magnesium Absorption Ratio; TH—Total Hardness RSBC—Residual Sodium Bicarbonate; KR-Kelly's Ratio.

a large number of irrigation waters varying in ionic relationships and concentration. The permeability index is given by the following formula:

$$
\mathrm{PI}=\frac{\left(\mathrm{Na}+\mathrm{HCO}_{3}\right) \times 100}{(\mathrm{Ca}+\mathrm{Mg}+\mathrm{Na})} .
$$

The plotted points has been shown that most of the points fall in the areas which are not good for irrigation Figure 17.

\subsection{Domestic Suitability}

Piper's [41] trilinear diagram is very important to assess the geochemical evaluation of groundwater. It consists of two lower triangular fields and a central diamond shaped field, all the three fields have scales reading in 100 parts. The percentage reacting values of the cations and the anions are plotted as a single point (according to the trilinear coordinates) at the lower left and right triangles, respectively. These are projected upwards parallel to the sides of the triangles to give a point in the rhombus. The point is represented by a circle whose area is proportional to the absolute concentration (actual pm) of the water. The water quality types can be qui ckly identified by the location of points in the different zones of the diamond-shaped field as shown in Figure 18. 


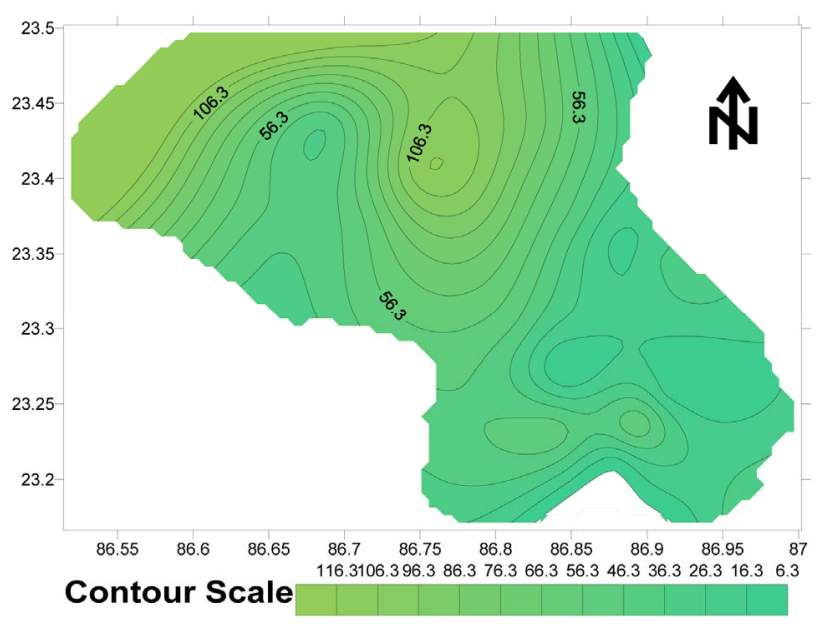

(a)

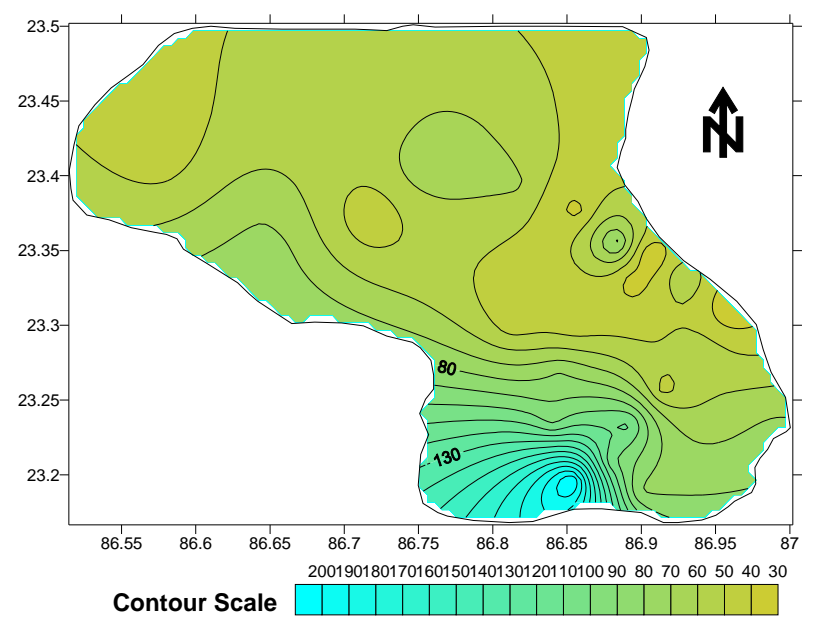

(b)

Figure 11. Calcium contour map: (a) Pre-monsoon; (b) Post-monsoon.

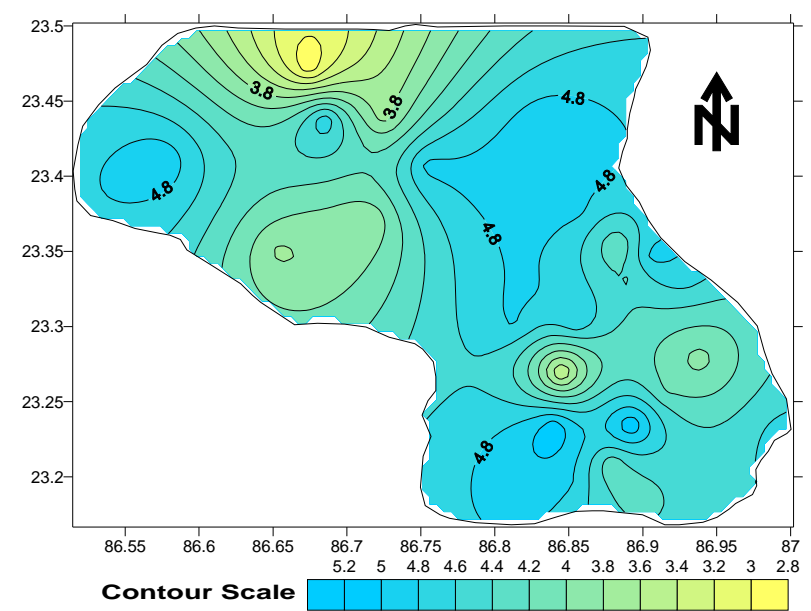

(a)

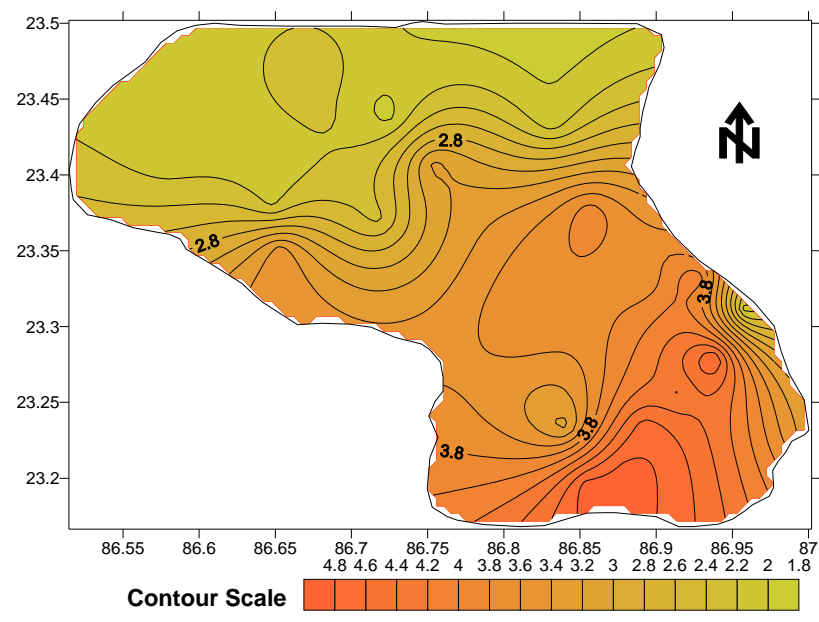

(b)

Figure 12. Magnesium contour map: (a) pre-monsoon; (b) post-monsoon.

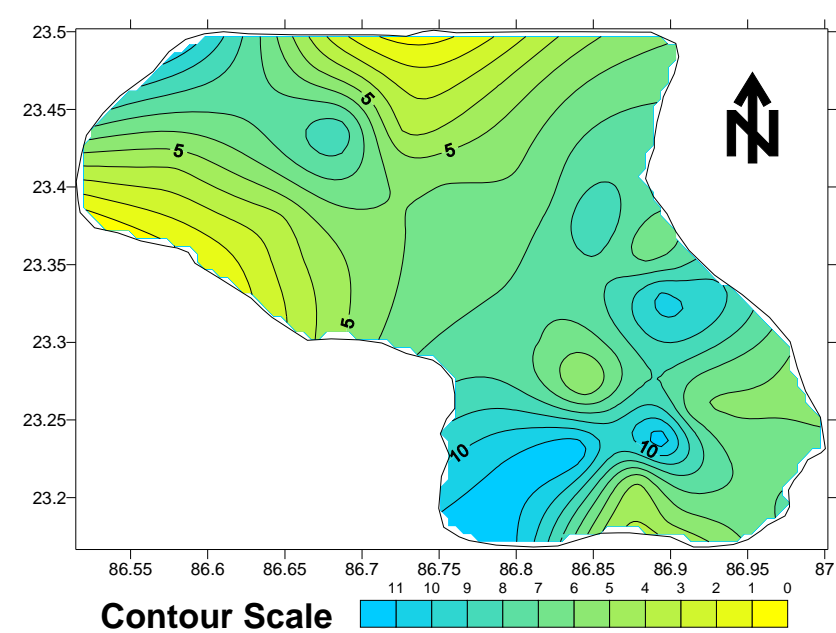

(a)

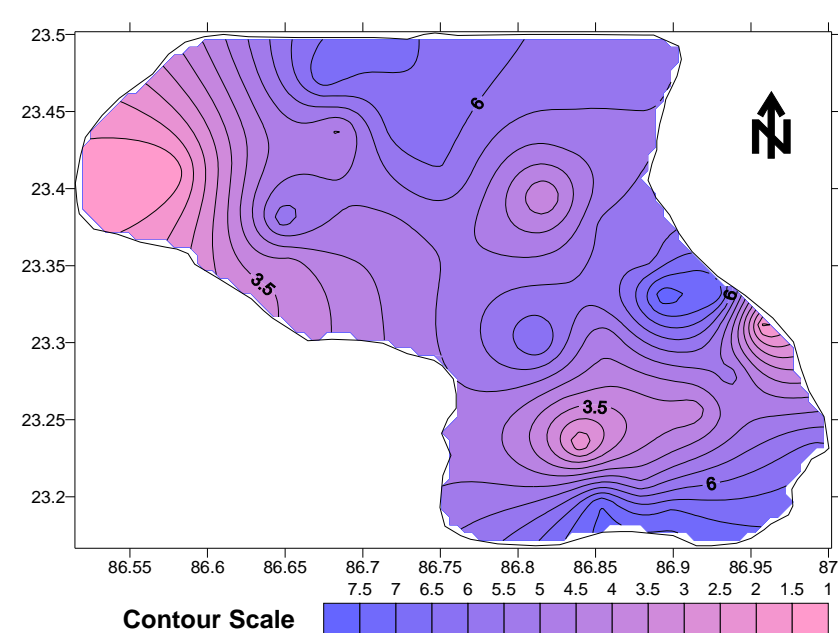

(b)

Figure 13. Sodium contour map: (a) pre-monsoon; (b) post-monsoon. 


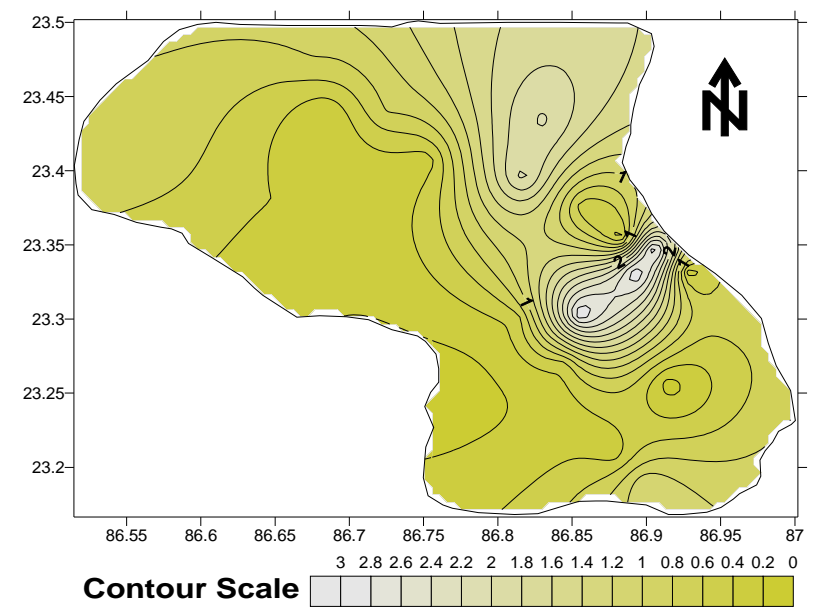

(a)

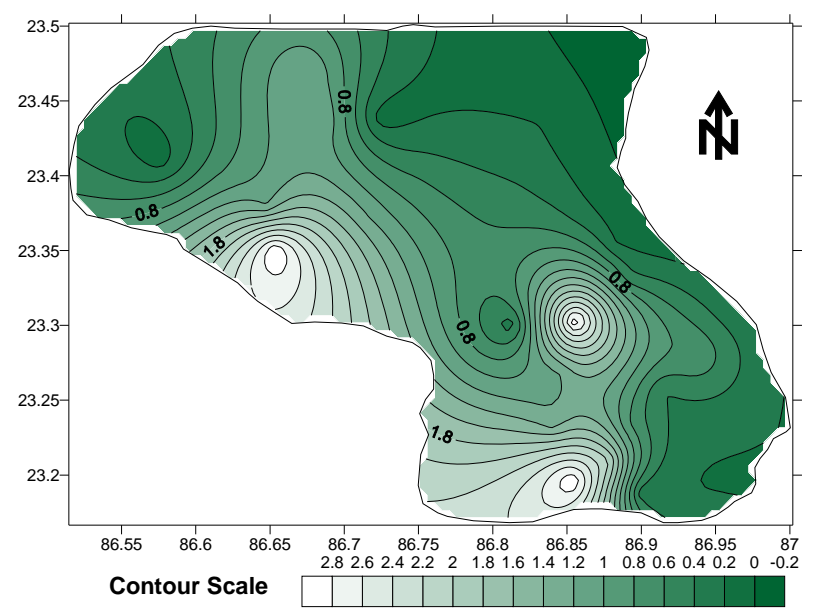

(b)

Figure 14. Iron contour map: (a) pre-monsoon; (b) post-monsoon.

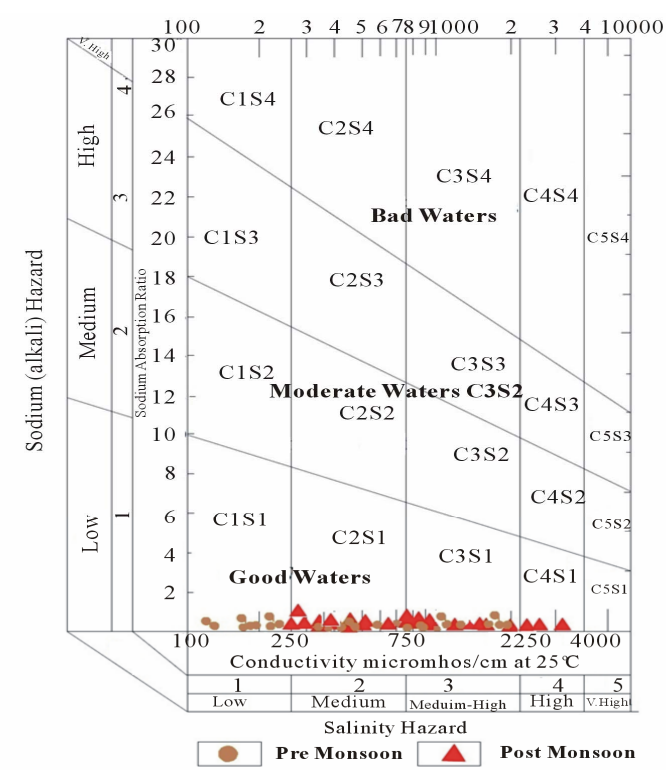

Figure 15. US salinity diagram.

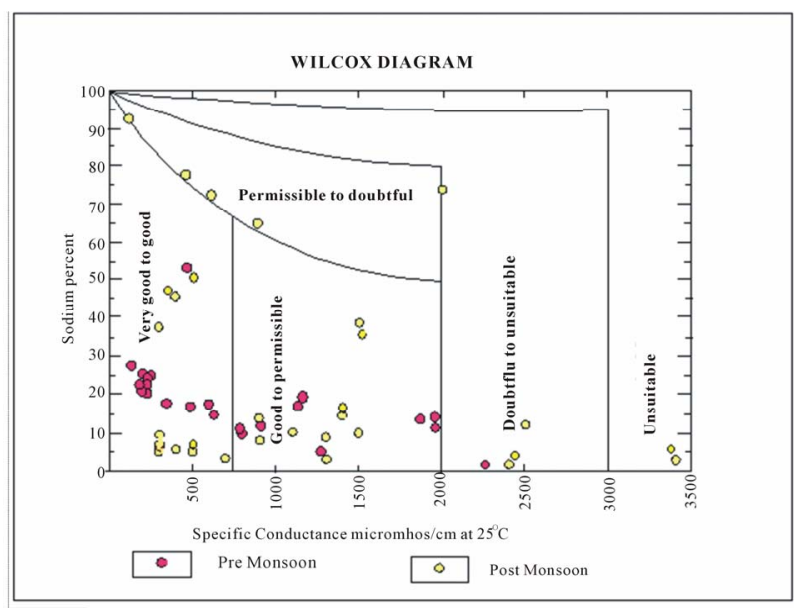

Figure 16. Wilcox diagram.

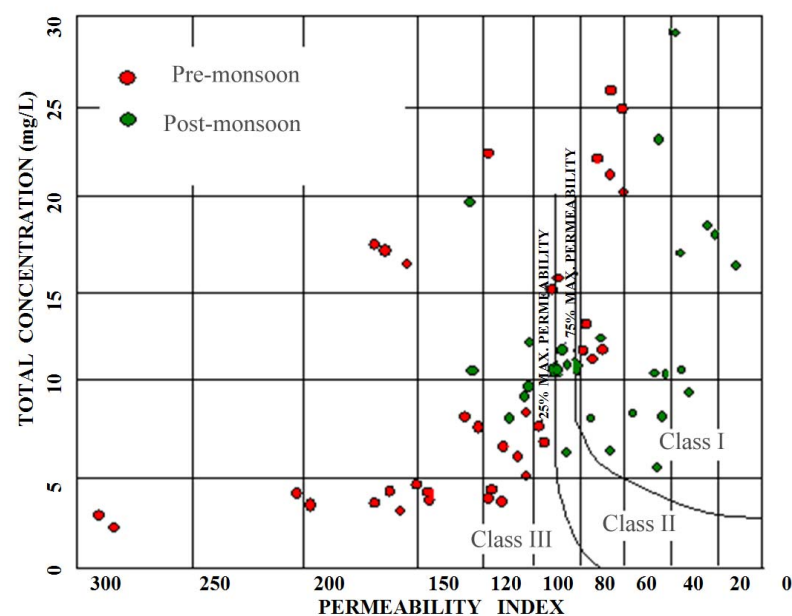

Figure 17. Permeability index diagram.

\section{Conclusions}

One of the most important use of groundwater is for drinking purpose. Hence, it is essential to ascertain the quality of groundwater because the presence of some minerals beyond certain limits may be unsuitable for drinking.

BIS, Government of India [42] has evolved a set of specifications for water to be used for drinking purposes. These are presented in Table $\mathbf{3}$ and, when compared with the analyzed samples of the study area, it is found that the groundwater is within the safe category, except for few places where higher values of iron and total hardness exist. In general, it may be stated that groundwater of the study area falls within safe category. Hence, the study has helped to improve understanding of physicochemical parameters of the area for effective management and proper utilization of groundwater resources for better living conditions of the people. A continuous monitoring 


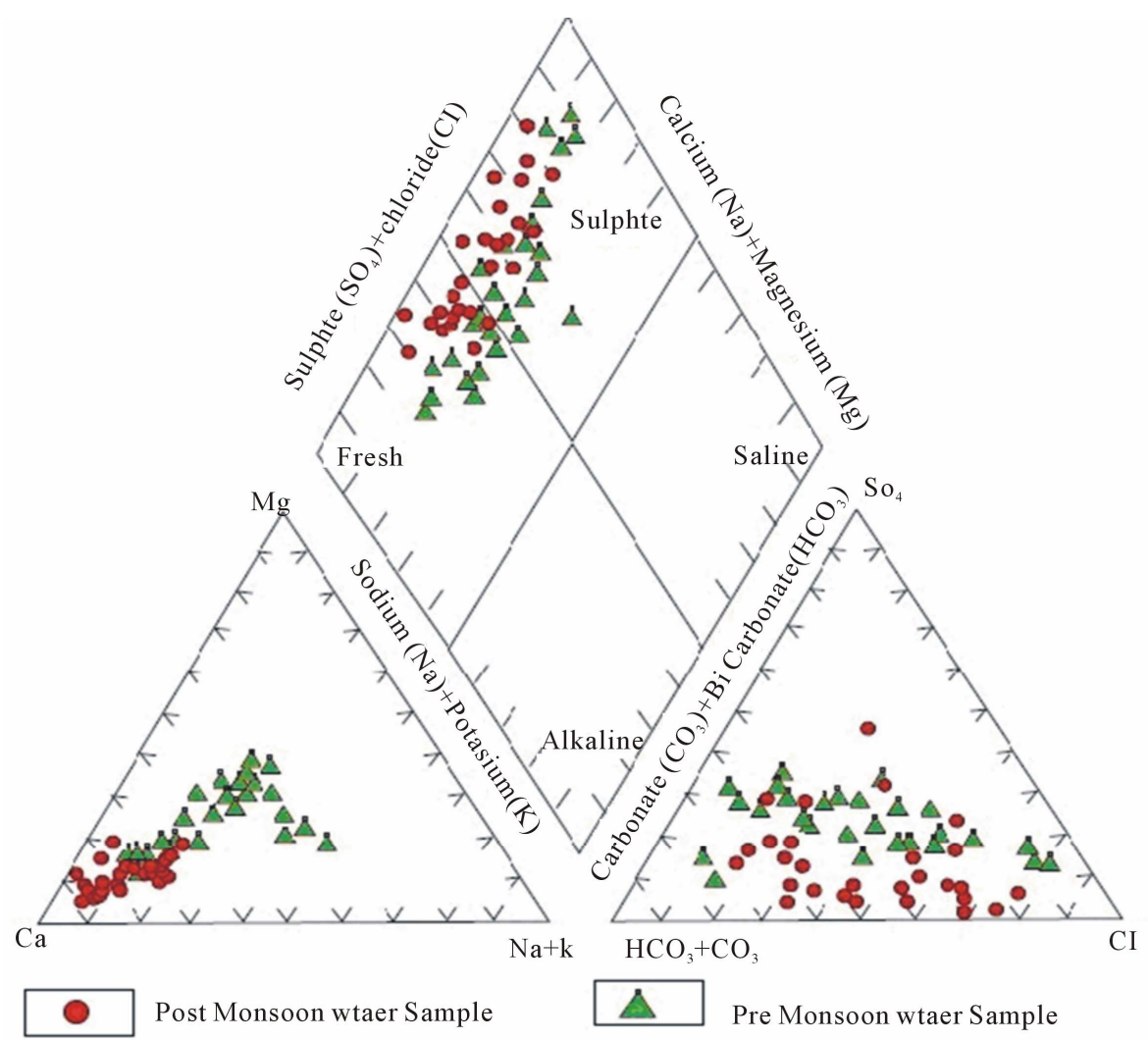

Figure 18. Piper trilinear diagram.

Table 3. Comparison of chemical analyses data with BIS, Govt. of India (pre-monsoon and post-monsoon, 2009).

\begin{tabular}{|c|c|c|c|c|c|c|c|}
\hline \multirow{2}{*}{$\begin{array}{l}\text { Sample } \\
\text { No. }\end{array}$} & \multirow{2}{*}{ Constituents } & \multirow{2}{*}{$\begin{array}{l}\text { Limits of General } \\
\text { Acceptability }\end{array}$} & \multirow{2}{*}{$\begin{array}{l}\text { Allowable } \\
\text { Limit }\end{array}$} & \multicolumn{2}{|c|}{ Analysed Samples } & \multicolumn{2}{|c|}{ Remarks } \\
\hline & & & & Pre-Monsoon & Post-Monsoon & Pre-Monsoon & Post-Monsoon \\
\hline 1. & $\mathrm{pH}$ & $7-8$ & $0.5-9.2$ & $6-8$ & $6.2-8.1$ & Within the limit & Within the limit \\
\hline 2. & $\begin{array}{l}\text { Total Dissolved Solid } \\
(\mathrm{mg} / \mathrm{L})\end{array}$ & 500 & 1500 & $83-1242$ & $92-1365$ & Within the limit & Within the limit \\
\hline 3. & $\begin{array}{l}\text { Specific Conductivity } \\
\left(\text { at } 25^{\circ} \mathrm{C}\right) \mu \mathrm{S} / \mathrm{cm}\end{array}$ & Below 780 & - & $140-1940$ & $200-3400$ & $\begin{array}{c}\text { Satyatan Primary } \\
\text { School, Teghari, } \\
\text { Gara, and } \\
\text { Goaldanga having } \\
\text { more than } 800 \\
\mu \mathrm{S} / \mathrm{cm} .\end{array}$ & Within the limit \\
\hline 4. & $\begin{array}{c}\text { Total Hardness } \\
\left(\text { as } \mathrm{CaCO}_{3}\right)(\mathrm{mg} / \mathrm{L})\end{array}$ & 300 & 600 & $90-1190$ & $20-1070$ & $\begin{array}{c}\text { Teghari and Gara } \\
\text { having more than } \\
1000 \mathrm{mg} / \mathrm{L} \text { of } \mathrm{CaCO}_{3} \text {. } \\
\text { Satyatan Primary } \\
\text { School has } 870 \mathrm{mg} / \mathrm{L} \\
\text { of } \mathrm{CaCO}_{3} .\end{array}$ & $\begin{array}{l}\text { Teghari and Gara, } \\
\text { Dwarkeswar River } \\
\text { Bed having more than } \\
1000 \mathrm{mg} / \mathrm{L} \text { of } \mathrm{CaCO}_{3} .\end{array}$ \\
\hline 5. & Calcium (mg/L) & 75 & 200 & $6.39-113.74$ & $30.06-214.23$ & Within the limit & Within the limit \\
\hline 6. & Magnessium (mg/L) & 50 & 150 & $2.84-5.22$ & $1.93-4.88$ & Within the limit & Within the limit \\
\hline 7. & Iron (mg/L) & 0.3 & 1.0 & $0.1-3$ & $0-3$ & $\begin{array}{c}\text { Kamalpur, } \\
\text { Sukhnibash, } \\
\text { Jhatipahari has } 3 \\
\mathrm{mg} / \mathrm{L} \text { of } \mathrm{Fe} \text { and also } \\
\text { Kanudi, has } 1.2 \mathrm{mg} / \mathrm{L} \\
\text { of } \mathrm{Fe} \text { in water }\end{array}$ & $\begin{array}{c}\text { Kamalpur, } \\
\text { Sukhnibash, } \\
\text { Jhatipahari and } \\
\text { Damankiari has } 3 \\
\mathrm{mg} / \mathrm{L} \text { of Fe and also } \\
\text { Kanudi, has } 1.2 \mathrm{mg} / \mathrm{L} \\
\text { of } \mathrm{Fe} \text { in water }\end{array}$ \\
\hline 8. & Chloride (mg/L) & 200 & 600 & $10-660$ & $20-580$ & $\begin{array}{l}\text { Teghari and Gara has } \\
\text { more than } 600 \mathrm{mg} / \mathrm{L} \\
\text { of } \mathrm{Cl} \text { in water }\end{array}$ & Within the limit \\
\hline
\end{tabular}


program of water quality is required to avoid further deterioration of the water quality of the study area.

\section{Acknowledgements}

The author (SKN) greatfullly acknowledges the financial support from Centre of Advanced Study (CAS-Phase IV), Department of Geological Sciences, Jadavpur University in conducting the field work related to this work. The other author (A. Lahiri) is thankful to University Grants Commission, New Delhi and Jadavpur University also for providing the UGC Research Fellowship in Science for Meritorious Student 2007-2008 to her.

\section{REFERENCES}

[1] R. H. Ganesh and Y. S. Kale, "Quality of Lentic Waters of Dharwad District in North Karnataka," Indian Journal of Environmental Health, Vol. 37, No. 1, 1995, pp. 52-56.

[2] H. Bouwer, "Integrated Water Management: Emerging Issues and Challenges," Agricultural Water Management, Vol. 45, No. 3, 2000, pp. 217-228.

[3] D. K. Todd, "Groundwater Development in an Arid Environment," Geoenvironment 2000 Conference, American Society of Civil Engineers, Reston, 1995, pp. 1429-1449.

[4] I. Raj, "Issues and Objectives in Groundwater Quality Monitoring Programme under Hydrology Project," Proceedings of National Symphony Groundwater Quality Monitoring, Bangalore, 2000, pp. 1-7.

[5] M. S. Olaniya and K. L. Saxena, "Groundwater Pollution by Open Refuse Dumps, Environmental Health, Vol. 19, No. 3, 1977, pp. 176-188.

[6] R. J. Gillison and C. R. Patmont, "Lake Phosphorus Loading from Septic Systems by Seasonally Perched Groundwater," Journal of the Water Pollution Control Federation, Vol. 55, No. 10, 1983, pp. 1297-1304.

[7] C. Eison and M. P. Anderson, "The Effects of Urbanization on Groundwater Quality," In: R. E. Jackson, Ed., Aquifer Contamination and Protection, UNESCO Press, Paris, 1980, pp. 378-390.

[8] H. Sharma and B. K. Kaur, "Environmental Chemistry," Goel Publishing House, Meerut, 1995.

[9] C. Subba Rao and N. V. Subba Rao, "Groundwater Quality in a Residential Colony," Indian Journal of Environmental Health, Vol. 37, No. 4, 1995, pp. 295-300.

[10] A. K. Banerji, "Importance of Evolving a Management Plan for Groundwater Development in the Calcutta Region of the Bengal Basin in Eastern India," Proceedings of International Symposium Groundwater Resources and Planning, Koblent, 28 August-3 September 1983, pp. 4554.

[11] B. K. Handa, "Hydrochemical Zones of India," Proceedings of Seminar on Groundwater Development, Roorkee, 1986, pp. 439-450.

[12] S. Ramachandra, A. Narayanan and N. V. Pundarikathan, "Nitrate and Pesticide Concentrations in Groundwater of Cultivated Areas in North Madras," Indian Journal of
Environmental Health, Vol. 33, No. 4, 1991. pp. 421-424.

[13] N. C. Datta and S. Sen Gupta, "Effect of Artificial Aeration on the Hydrographic Regime of Pesticide Treated Aquatic System," Journal of Pollution Research, Vol. 15, No. 4, 1996, pp. 329-333.

[14] R. K. Somashekar, V. Rameshaiah and A. Chethana Suvarna, "Groundwater Chemistry of Channapatna Taluk (Bangalore Rural District)-Regression and Cluster Analysis," Journal of Environment and Pollution, Vol. 7, No. 2, 2000, pp. 101-109.

[15] S. Rengaraj, T. Elampooranan, L. Elango and V. Ramalingam, "Groundwater Quality in Suburban Regions of Madras City, India," Journal of Pollution Research, Vol. 15, No. 4, 1996, pp. 325-328.

[16] K. P. Singh, "Environmental Effects of Industrialization of Groundwater Resources: A Case Study of Ludhaina Area, Punjab, India," Proceedings of international Symphony on Soil, Geology and Landform-Impact of Land Uses in Developing Countries, Bangkok, 1982, pp. E6.1E6.7.

[17] M. Singh, S. Kaur and S. S. Sooch, "Groundwater Pollution-An Overview," Journal of the Institute of Plumbing and Heating Engineering, Vol. 2, 2003, pp. 29-31.

[18] L. Elango and S. Manickam, "Hydrogeochemistry of the Madras Aquifer, India-Spatial and Temporal Variation in Chemical Quality of Groundwater," Geological Society of Hong Kong Bulletin, No. 3, 1987, pp. 525-534.

[19] R. Ramesh, "Groundwater Quality Management: Pollution Perspectives Impacts of Urban Growth on Surface Water and Groundwater Quality," Proceedings of IUGG 99 Symposium HS5, Birmingham, July 1999, pp. 47-55.

[20] N. Rajmohan, L. Elango, S. Ramachandran and M. Natrajan, "Major Ion Correlation in Groundwater of Kancheepuram Region, South India," Indian Journal of Environmental Protection, Vol. 20, No. 3, 2000, pp. 188-193.

[21] L. Elango, R. Kannan and M. Senthilkumar, "Major Ion Chemistry and Identification of Hydrogeochemical Processes of Groundwater in a Part of Kancheepuram District, Tamil Nadu, India," Environmental Geosciences, Vol. 10, No. 4, 2003, pp. 1-10.

[22] L. Elango, S. S. Kumar and N. Rajmohan, "Hydrochemical Studies of Groundwater in Chengalpet Region," Indian Journal of Environmental Protection, Vol. 23, No. 6, 2003, pp. 624-632.

[23] M. Kumaresan and P. Riyazuddin, "Major Ion Chemistry of Environmental Samples around Sub-Urban of Chennai City," Current Science, Vol. 91, No. 12, 2006. pp. 16681677.

[24] APHA, "Standard Methods for the Examination of Water and Wastewater," 20th Edition, APHA, San Francisco, 1998.

[25] M. Detay, P. Poyet, Y. Emsellem, A. Bernardi and G. Aubrac, "Development of the Saprolite Reservoir and Its State of Saturation: Influence on the Hydrodynamic Characteristics of Drillings in Crystalline Basement (in French)," Comptes Rendus de l'Académie des Sciences, Série II, Vol. 309, 1989, pp. 429-436.

[26] R. Taylor and K. Howard, "A Tectono-Geomorphic 
Model of the Hydrogeology of Deeply Weathered Crystalline Rock: Evidence from Uganda," Hydrogeology, Vol. 8, No. 3, 2000, pp. 279-294. doi:10.1007/s100400000069

[27] R. Wyns, J. M. Baltassat, P. Lachassagne, A. Legchenko, J. Vairon and F. Mathieu, "Application of SNMR Soundings for Groundwater Reserves Mapping in Weathered Basement Rocks (Brittany, France)," Bulletin de la Societe Geologique de France, Vol. 175, No. 1, 2004, pp. 21-34. doi:10.2113/175.1.21

[28] WHO, "Guidelines for Drinking Water Quality," 3rd Edition, World Health Organization, Geneva, 2004.

[29] A. Garrels, "Survey of Low Temperature Water Mineral Relations in Interpretation of Environmental Isotope and Hydrogeochemical Data in Groundwater Hydrology," International Atomic Energy Agency, Vienna, 1976.

[30] C. V. Moore, "Modern Nutrition in Health and Disease," Lea and Febiger, Philadelphia, 1973, p. 297.

[31] F. J. Dart, "The Hazard of Iron," Water and Pollution Control, Ottawa, 1974.

[32] A. Navarro and M. E. Camonal, "Evaluation of Groundwater Contamination Beneath an Urban Environment: The Beso's River Basin (Barcelona, Spain)," Journal of Environmental Management, Vol. 85, No. 2, 2007, pp. 259-269. doi:10.1016/j.jenvman.2006.08.021

[33] I. Anithamary, "Hydrogeochemical and Environmental Geochemistry of Water in Kodiakarai Region-Coastal
Zone of Tamilnadu," M.Phil. Thesis, Annamalai University, Annamalainagar, 2008.

[34] L. A. Richards, "Diagnosis and Improvement of Saline and Alkali Soils," United States Department of Agriculture, Washington, 1954.

[35] D. K. Todd, "Ground Water Hydrogeology," John Wiley and Sons, Hoboken, 1980.

[36] L. V. Wilcox, "Salinity—A Hidden Danger," Cotton Trade Journal of 26th International Yearbook, 1959, pp. 58-64.

[37] S. K. Gupta and I. C. Gupta, "Management of Saline Soils and Water," Oxford and IBH Publication, Co., New Delhi, 1987.

[38] I. I. M. Raghunath, "Groundwater," 2nd Edition, Wiley Eastern Ltd., New Delhi, 1987, pp. 344-369.

[39] W. P. Kelly, "Use of Saline Irrigation Water," Soil Science, Vol. 95, No. 4, 1963, pp. 355-391.

[40] L. D. Doneen, "Notes on Water Quality in Agriculture," Water Science and Engineering Paper 4001, University of California, Davis, 1964.

[41] A. M. Piper, "A Graphical Procedure in the Geochemical Interpretation of Water Analysis," Transactions-American Geophysical Union, Vol. 25, 1944, pp. 914-928. doi:10.1029/TR025i006p00914

[42] Bureau of Indian Standards (BIS), "Drinking Water," 1st Revision, Government of India, New Delhi, 1991. 